\title{
In Vitro Kinase Inhibitor Assay
}

National Cancer Institute

\section{Source}

National Cancer Institute. In Vitro Kinase Inhibitor Assay. NCI Thesaurus. Code C153397.

Any of various laboratory assay methods designed to measure the kinase inhibition activity of a test compound. 